\title{
Cellular origins of adult human islet in vitro dedifferentiation
}

\author{
Stephen C Hanley ${ }^{1,2}$, Amélie Pilotte ${ }^{3,4}$, Bernard Massie ${ }^{3,4,5}$ and Lawrence Rosenberg ${ }^{1,2}$
}

Cultured human islets can be dedifferentiated to duct-like structures composed mainly of cytokeratin ${ }^{+}$and nestin $^{+}$cells. Given that these structures possess the potential to redifferentiate into islet-like structures, we sought to elucidate their specific cellular origins. Adenoviral vectors were engineered for $\beta-, \alpha-, \delta$ - or PP-cell-specific GFP expression. A doublestranded system was designed whereby cultures were infected with two vectors: one expressed GFP behind the cumateinducible promoter sequence, and the other expressed the requisite transactivator behind the human insulin, glucagon, somatostatin or pancreatic polypeptide promoter. This system labels hormone ${ }^{+}$cells in the islet in a cell-specific manner, allowing these cells to be tracked during the course of transformation from islet to duct-like structure. Post-infection, islets were cultured to induce dedifferentiation. Fluorescence microscopy demonstrated that $\alpha$-, $\delta$ - and PP-cells contributed equally to the cytokeratin ${ }^{+}$population, with minimal $\beta$-cell contribution, whereas the converse was true for nestin $^{+}$cells. Complementary targeted cell ablation studies, using streptozotocin or similar adenoviral expression of the Bax ( $\mathrm{BCl} 2$-associated $\mathrm{X}$ protein) toxigene, validated these findings and suggested a redundancy between $\alpha$-, $\delta$ - and PP-cells with respect to cytokeratin ${ }^{+}$cell derivation. These results call into question the traditional understanding of islet cells as being terminally differentiated and provide support for the concept of adult islet morphogenetic plasticity.

Laboratory Investigation (2008) 88, 761-772; doi:10.1038/labinvest.2008.41; published online 19 May 2008

KEYWORDS: $\beta$-cell; cell lineage; differentiation; islet; plasticity

Pancreatic $\beta$-cell mass is tightly regulated, ${ }^{1-3}$ reflecting the net effect of homeostatic mechanisms that include proliferation, neogenesis and apoptosis. ${ }^{4}$

With respect to neogenesis, small clusters of $\beta$-cells in close proximity to pancreatic ducts are taken as a surrogate measure ${ }^{5,6}$ given that this is the mechanism by which islets form during pancreatic organogenesis. ${ }^{7}$ Reports also suggest that pancreatic acinar tissue may serve as a source of new islets, either directly ${ }^{8}$ or through duct-like intermediates. ${ }^{9}$ Intraislet progenitors have also been implicated. ${ }^{10-13}$ In fact, varying degrees of islet-like morphology and function have been reported in cultures derived from non-endocrine pancreatic cell sources. ${ }^{14-16}$ Unfortunately, the lineage relationships that exist between pancreatic cell types, and the extent to which this plasticity contributes to pancreatic $\beta$-cell mass dynamics, are highly controversial. ${ }^{17,18}$ For example, the physiological relevance of islet neogenesis as a mechanism of $\beta$-cell renewal or regeneration has been questioned by lineage tracing studies in mice. ${ }^{19,20}$ Nonetheless, elucidation of these cellular inter-relationships may be key to the development of novel diabetes therapies.

Notwithstanding this controversy, several groups, ${ }^{21-25}$ including our own, ${ }^{26}$ have reported that cultured adult human islets dedifferentiate into proliferative precursor-type cells, expressing either cytokeratins (CK) or nestin. These cells can in turn be induced to redifferentiate into islet-like structures, given the appropriate stimulus. Preliminary results of ultrastructural, $^{26}$ immunofluorescence ${ }^{22,25,26}$ and pulse-chase ${ }^{21}$ experiments suggest that these precursor-type cells are of endocrine origin. To provide more conclusive evidence, recent studies have used islets from mice marked using in vivo lineage tracing techniques. ${ }^{27-30}$ Chase et al cultured islets isolated from mice engineered to express GFP in cells having had an active pancreatoduodenal homeobox gene-1 $(P d x 1)$ promoter, ${ }^{28}$ indelibly marking cells of all pancreatic lineages. ${ }^{31}$ After culture, few if any $\mathrm{GFP}^{+}$precursor-type cells were identified, consistent with a non-pancreatic origin. However, minimal islet redifferentiation has been reported

\footnotetext{
${ }^{1}$ Department of Surgery, McGill University, Montréal, QC, Canada; ${ }^{2}$ Centre for Pancreatic Diseases, McGill University Health Centre, Montréal, QC, Canada; ${ }^{3}$ Biotechnology Research Institute, Montréal, QC, Canada; ${ }^{4}$ Department of Microbiology and Immunology, University of Montréal, Montréal, QC, Canada and ${ }^{5}$ INRS-IAF, University of Québec, Laval, QC, Canada Correspondence: Dr L Rosenberg, MD, PhD, Montreal General Hospital C9-128, 1650 Cedar avenue, Montréal, QC, Canada H3G 1 A4.

E-mail: lawrence.rosenberg@mcgill.ca
} 
from cultured mouse islets, ${ }^{27-30}$ suggesting an innate difference between mouse and human islet-derived cells. ${ }^{2,32}$ In fact, a most recent lineage tracing study indicated that human $\beta$-cells were capable of in vitro dedifferentiation whereas murine $\beta$-cells were not. ${ }^{33}$

The aim of this study was to establish the cellular origins of human islet-derived precursor-type cells, using adenoviral vectors to specifically label individual endocrine cell types. Identifying the exact source of precursor-type cells is a necessary prelude to the development of techniques for scaling up this process.

\section{MATERIALS AND METHODS}

Adenoviral vectors were engineered for $\beta$-, $\alpha-, \delta$ - or PP-cellspecific expression (Table 1). A double-stranded system was designed whereby cultures were infected with two vectors: one expressed the marker (GFP or Bax (Bcl2-associated
$\mathrm{X}$ protein)) behind the cumate-inducible promoter sequence $^{34,35}$ and the other expressed the requisite transactivator behind the promoter sequence of interest. In this way, even low promoter activity would be sufficient to induce expression of the transactivator, in turn amplifying the signal $^{34}$ with minimal delay. ${ }^{36}$ Similar coinfection systems have been used with some success in isolated islets. ${ }^{37,38}$ Comparison of this system to GFP expression controlled directly by the insulin promoter confirmed signal amplification (data not shown).

\section{Cell Culture}

The 293 cell line (ATCC, Manassas, VA, USA), the 293CR5GFP cell line that stably expresses GFP under the control of the cumate-inducible promoter ${ }^{35}$ and the BMAdE1 cell line (Qbiogene, Irvine, CA, USA) were grown in DMEM

Table 1 Adenoviral vectors

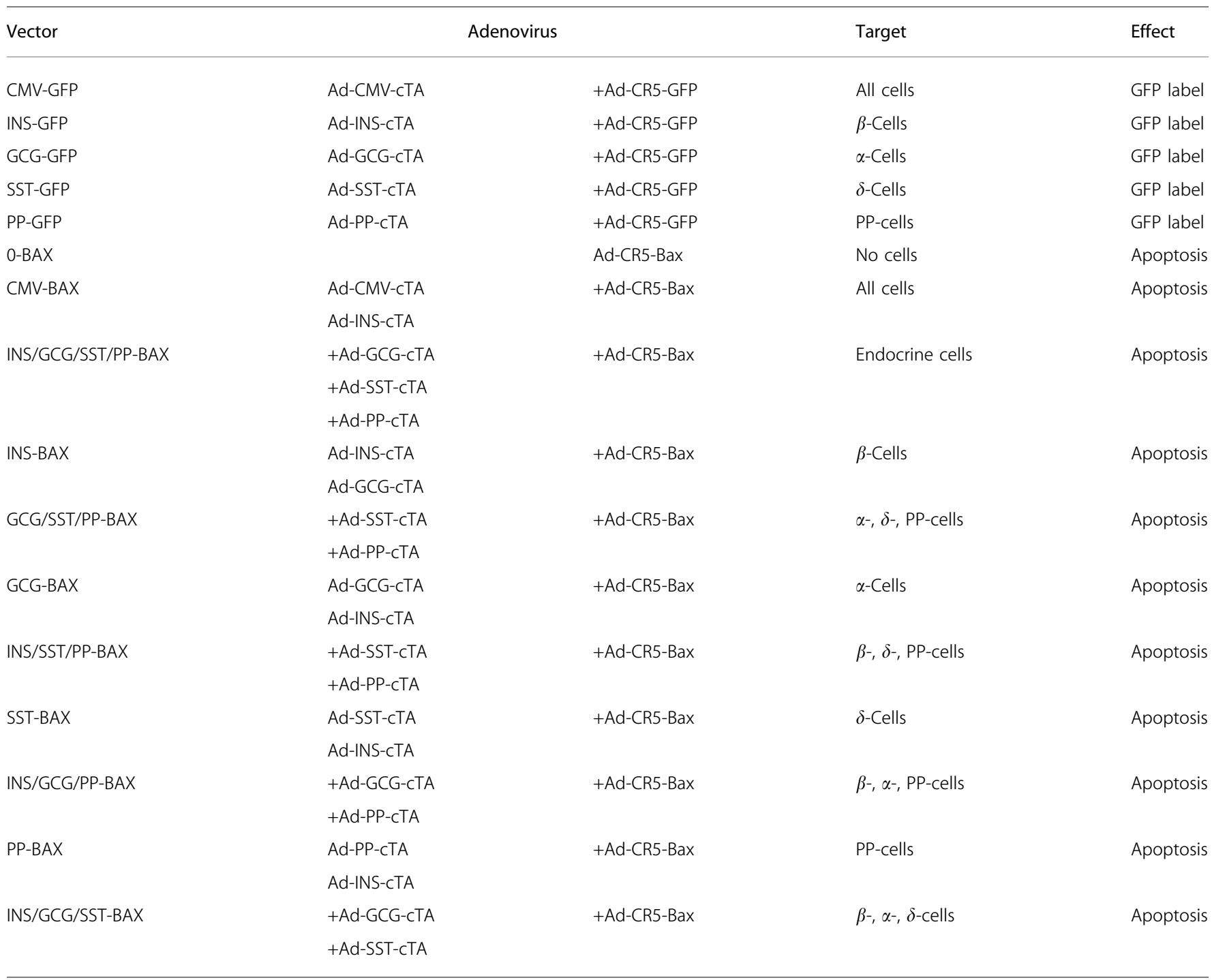


(Wisent, St-Bruno, QC, Canada) containing 5\% serum and $2 \mathrm{mM}$ L-glutamine.

\section{Plasmids}

Plasmids containing cTA behind the promoter sequence of interest (pAd-promoter-cTA) were constructed by replacing the cytomegalovirus (CMV) promoter portion of the pAdPS-CMV-cTA-DC-GFP plasmid ${ }^{35}$ with the promoter sequence of interest (Table 2), amplified by PCR from genomic DNA extracted from 293 cells using the DNeasy tissue kit (Qiagen, Mississauga, ON, Canada).

Plasmid containing Bax controlled by the CR5 promoter (pAd-CR5-Bax) was constructing by inserting the Bax coding sequence (a generous gift from Dr B Fang, University of Texas MD Anderson Cancer Center $)^{46}$ in place of GFP in the pAd-CR5-GFP vector.

\section{Adenoviral Production}

pAd-promoter-cTA plasmids were used to produce adenoviral vectors, using a positive selection method based on the rescue of protease-, E1- and E3-deficient adenoviruses (Qbiogene), as previously described. ${ }^{47,48}$ Homogeneously green fluorescent plaques on 293CR5GFP were picked and eluted.

Recombinant adenoviral vectors were amplified by consecutive passages in BMAdE1 cells, except for the last passage, which was in $293 \mathrm{~A}$ cells, as per standard procedures. Adenoviruses were purified by centrifugation on $\mathrm{CsCl}$ gradients using standard procedures. Viral titer was determined by plaque assay on 293CR5GFP cells, as described previously. ${ }^{49}$

The adenoviral vector expressing GFP under the control of the cumate-inducible promoter (Ad-CR5-GFP) has been described previously. ${ }^{35}$ The adenoviral vector expressing Bax under the control of the cumate-inducible promoter (Ad-CR5-Bax) was produced as described above.

\section{Islet Isolation}

Pancreata from adult human cadaveric organ donors were obtained through the local organ procurement organization
(Table 3). Islets were isolated according to established protocols. ${ }^{50}$ Free islets with diameters ranging from 75 to $400 \mu \mathrm{m}$, determined to be greater than $75 \%$ pure by real-time staining with dithizone (Sigma, St Louis, MO, USA), a $\mathrm{Zn}^{2+}$ chelator, were collected, washed and counted as islet equivalents $(\mathrm{IE}=$ islet with a diameter of $150 \mu \mathrm{m})$.

\section{Islet Infection}

Islets were infected 2 days post-isolation, at a density of $2500 \mathrm{IE} / \mathrm{ml}$ and an MOI of 5000/IE for Ad-CR5-GFP or Ad-CR5-Bax, and an MOI of 50000/IE for Ad-promotercTA. After $6 \mathrm{~h}$, the medium was added to a density of 1000 $\mathrm{IE} / \mathrm{ml}$. Islets were further incubated for 4 days to allow marker expression to develop before culturing to form duct-like structures (DLS). Controls included mock infection, infection with Ad-CR5-GFP or Ad-CR5-Bax alone (MOI of 5000/IE), or in combination with Ad-CMV-cTA (MOI of $50000 / \mathrm{IE}$ ).

Table 3 Donor and isolation characteristics

\begin{tabular}{lccc}
\hline & Study isolations & $\begin{array}{c}\text { Isolations } \\
2005-2007^{\text {a }}\end{array}$ & $P$ \\
\hline$n$ & 17 & 61 & \\
Age (years) & $51.5 \pm 3.5$ & $52.2 \pm 1.8$ & NS \\
Sex (\% male) & 47 & 58 & NS \\
BMl (kg/m ${ }^{2}$ ) & $29.4 \pm 1.0$ & $27.4 \pm 0.6$ & NS \\
Cause of death (\% traumatic) & 38 & 27 & NS \\
ICU duration (days) & $2.8 \pm 0.5$ & $2.5 \pm 0.3$ & NS \\
Glucose (mM) & $9.5 \pm 0.7$ & $9.1 \pm 0.4$ & NS \\
Amylase (U/l) & $193 \pm 64$ & $213 \pm 39$ & NS \\
Cold ischemia (h) & $7.7 \pm 1.1$ & $6.7 \pm 0.7$ & NS \\
Yield $\geq 70 \%$ pure (IE) & $306727 \pm 30268$ & $272267 \pm 22009$ & NS
\end{tabular}

andicates all isolations performed during the calendar years 2005-2007.

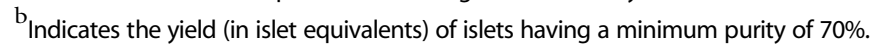

Table 2 Promoter sequences

\begin{tabular}{|c|c|c|c|}
\hline Gene & Position & Primers & Reference \\
\hline \multirow[t]{2}{*}{ INS } & -717 to -170 & $5^{\prime}$-गाтCTCGAGACAGGGGTGTGGGGACAG-3' & 39,40 \\
\hline & & 5'-GCTTTGATATCCCTGACGCAAAGGCCCTG-3' & \\
\hline \multirow[t]{2}{*}{ GCG } & -3660 to -2931 & $5^{\prime}$-CGGAACTCGAGAAACAGAACACATAGGGGT-3' & 41,42 \\
\hline & & 5'-CTGAGATATCCTTCACTGTCCGCCAAAC-3' & \\
\hline \multirow[t]{2}{*}{ SST } & -1075 to +158 & 5'-CCGCTCGAGGCTTCCTGACATAAAACTATGC-3' & 43,44 \\
\hline & & 5'-CTGGATATCGTCGAGGGAGTCTCCTTACC-3' & \\
\hline \multirow[t]{2}{*}{ PP } & -1740 to -766 & 5'-GCGGCGGGCGGATATCGTGGGAAATTATAACAATAC-3' & 45 \\
\hline & & $5^{\prime}$-GGCGGAGATCTAGAGTAAATGGGCACTAGAAC-3' & \\
\hline
\end{tabular}




\section{Streptozotocin Treatment}

In select groups, islets were pretreated with $5 \mathrm{mM}$ streptozotocin (STZ; Sigma), prepared in $0.1 \mathrm{M}$ citrate buffer ( $\mathrm{pH} 4.5$ ), for $30 \mathrm{~min}$ before embedding.

\section{Islet Culture}

Infected islets were washed in serum-free DMEM/F12 (Gibco, Burlington, ON, Canada) containing penicillin, streptomycin, fungizone, $1 \mu \mathrm{M}$ dexamethasone, $10 \mathrm{ng} / \mathrm{ml}$ EGF (Sigma), $24 \mathrm{mU} / \mathrm{ml}$ insulin (Lilly, Toronto, ON, Canada) and $200 \mathrm{ng} / \mathrm{ml}$ cholera toxin (Sigma) before embedding. Islets were then embedded in type I rat tail collagen, as per previous reports, ${ }^{51}$ at a density of $2000 \mathrm{IE} / 25 \mathrm{~cm}^{2}$ and cultured for 8 days in the above medium, with media changes every other day. To remove tissue from collagen, samples were incubated with $0.25 \mathrm{mg} / \mathrm{ml}$ collagenase XI (Sigma) for $30 \mathrm{~min}$ at $37^{\circ} \mathrm{C}$. To disperse cultures into single cells, samples were washed twice in HBSS before incubation in $0.05 \%$ trypsinEDTA (Invitrogen) for $10 \mathrm{~min}$ at $37^{\circ} \mathrm{C}$. Samples were then washed in serum-containing medium before fixing in $4 \%$ phosphate-buffered formalin at $4^{\circ} \mathrm{C}$.

In selected groups, spontaneous islet redifferentiation was assessed by switching DLS cultures to the above islet culture medium, with $10 \%$ serum but without cholera toxin, for 4 days (redifferentiation medium). Islet redifferentiation was also induced by adding $667 \mathrm{nM}$ islet neogenesis-associated protein (INGAP) peptide (Sheldon Biotech, Montréal, QC, Canada). ${ }^{26}$

\section{Immunofluorescence}

For immunofluorescence studies, samples of 4000 IE were dispersed into single cells and then aliquots were applied to microscopic slides by cytocentrifugation. Slides were then processed for immunofluorescence as per standard protocols. ${ }^{52}$ Antibodies used were rabbit $\alpha$-insulin (Santa Cruz Biotechnology, Santa Cruz, CA, USA), rabbit $\alpha$-glucagon, $\alpha$-somatostatin and $\alpha$-pancreatic polypeptide, mouse $\alpha$-CKAE1/AE3 (Dako, Carpinteria, CA, USA) and mouse $\alpha$-nestin (Abcam, Cambridge, MA, USA) primary antibodies, along with FITC- and rhodamine-linked $\alpha$-rabbit and $\alpha$-mouse secondary antibodies (Abcam). To assess cell death, samples were processed using a TUNEL kit (Roche). Images were captured using a Zeiss Axioskop 40 microscope and Northern Eclipse v6.0 (Empix Imaging, Mississauga, ON, Canada), and at least 400 cells were counted per sample (528 \pm 27 cells).

\section{Statistical Analysis}

All experiments were performed using islets from a minimum of three donors (the number of biological replicates is indicated in the figures and tables) and experiments were paired in that control and treatment groups from the same donor were compared. Results are expressed as mean \pm s.e.m. Statistical significance was determined by one-way ANOVA with a post hoc Bonferroni's test, or paired Student's $t$-test, when applicable. Differences were considered significant when $P<0.05$.

\section{RESULTS Islet Purity and Composition}

Immunofluorescence studies (Table 4) determined islet samples to be $72.7 \pm 5.0 \%$ hormone $^{+}$and $3.0 \pm 0.9 \% \mathrm{CK}^{+}$. A total of $0.3 \pm 0.4 \%$ were hormone ${ }^{+} / \mathrm{CK}^{+}$whereas $23.2 \pm 8.7 \%$ were hormone ${ }^{-} / \mathrm{CK}^{-}$and likely consisted of acinar and dead cells. Preparations also contained $5.2 \pm 1.1 \%$ nestin $^{+}$cells, although these cells were in fact nestin ${ }^{+} /$ insulin $^{+}$. Cell frequencies $(53: 28: 13: 5$ for $\beta: \alpha: \delta: \mathrm{PP})$ were in keeping with previous reports for human islets. ${ }^{53}$

\section{GFP Expression}

Following adenoviral infection, islet samples were collected to assess labeling efficiencies and specificities. Immunofluorescence microscopy analysis determined that cell typespecific vectors had highly reproducible labeling efficiencies (Table 5 and Figure 1a). It is the reproducibility of these labeling efficiencies and not the specific labeling efficiency that allows subsequent analyses. Moreover, these vectors

Table 4 Cell frequencies

\begin{tabular}{lrccc}
\hline Marker & Islet-day 0 (\%) & DLS-day 8 (\%) & $P$ & $n$ \\
\hline Insulin & $38.9 \pm 2.5$ & $2.4 \pm 0.9$ & $<0.001$ & 7 \\
Glucagon & $20.1 \pm 1.4$ & $3.1 \pm 0.7$ & $<0.001$ & 7 \\
Somatostatin & $9.2 \pm 1.1$ & $2.9 \pm 0.6$ & $<0.001$ & 7 \\
Pancreatic polypeptide & $4.0 \pm 0.5$ & $2.9 \pm 0.5$ & 0.056 & 7 \\
Total endocrine & $72.7 \pm 5.0$ & $11.3 \pm 2.0$ & $<0.001$ & 7 \\
Cytokeratin & $3.0 \pm 0.9$ & $40.3 \pm 3.7$ & $<0.001$ & 8 \\
Nestin & $5.2 \pm 1.1$ & $17.6 \pm 2.4$ & $<0.001$ & 8 \\
\hline
\end{tabular}

DLS, duct-like structures.

Table 5 Labeling efficiencies and specificities

\begin{tabular}{lccr}
\hline Vector & Efficiency (\%) & Specificity $(\%)^{\mathrm{b}}$ & $n$ \\
\hline INS-GFP & $35.0 \pm 3.4$ & $97.1 \pm 1.7$ & 4 \\
GCG-GFP & $49.8 \pm 0.8$ & $99.1 \pm 1.1$ & 3 \\
SST-GFP & $46.3 \pm 3.2$ & 100 & 4 \\
PP-GFP & $43.9 \pm 1.9$ & 100 & 3
\end{tabular}

andicates the fraction of hormone ${ }^{+}$cells (for the promoter of interest) also found to be $\mathrm{GFP}^{+}$, and indicates the cell type-specific labeling efficiency of the individual vectors. General infection efficiency was $46.5 \pm 1.0 \%$, as assessed using a CMV-GFP infection $(n=3)$.

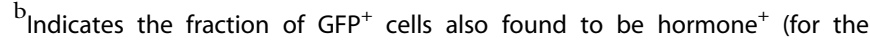
promoter of interest), and indicates the cell type specificity of the individual vectors. 
a

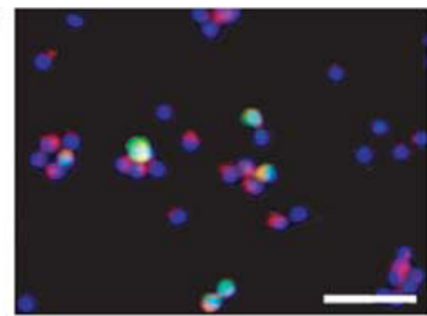

INS-GFP INS

b

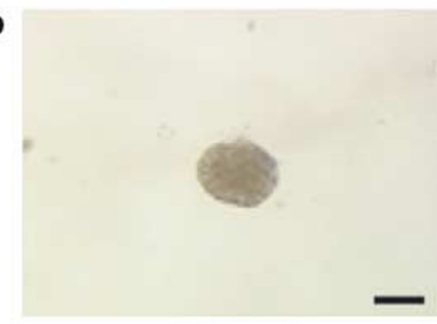

islet (day 0)

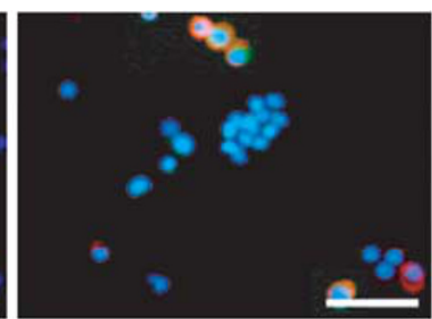

GCG-GFP GCG

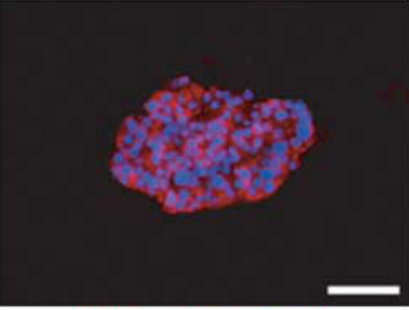

INS+GCG+SST+PP

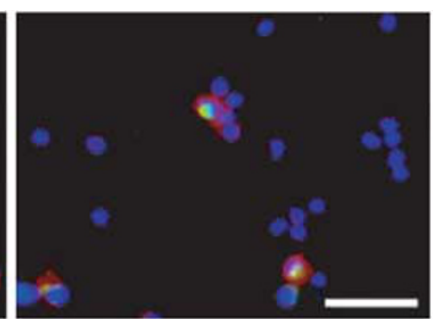

SST-GFP SST

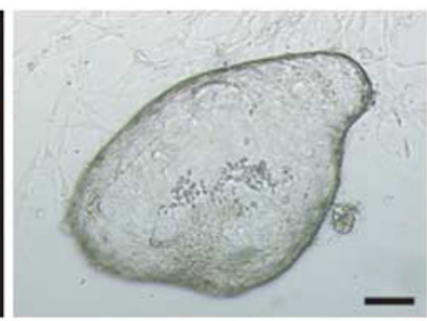

DLS (day 8)

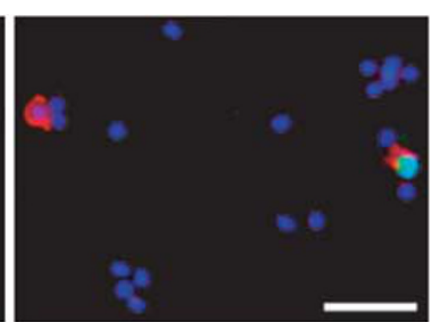

PP-GFP PP

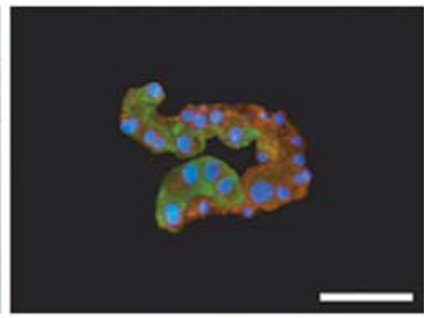

nestin cytokeratin
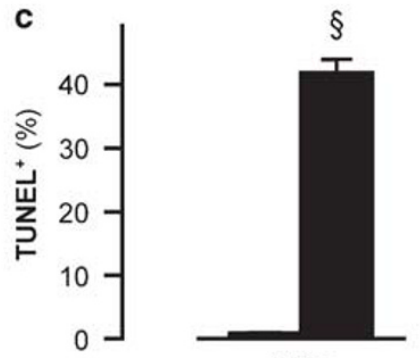

INS $^{+}$

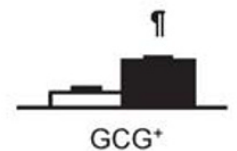

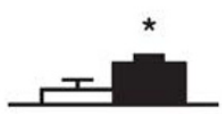

$\mathrm{SST}^{+}$

day 0

day 2

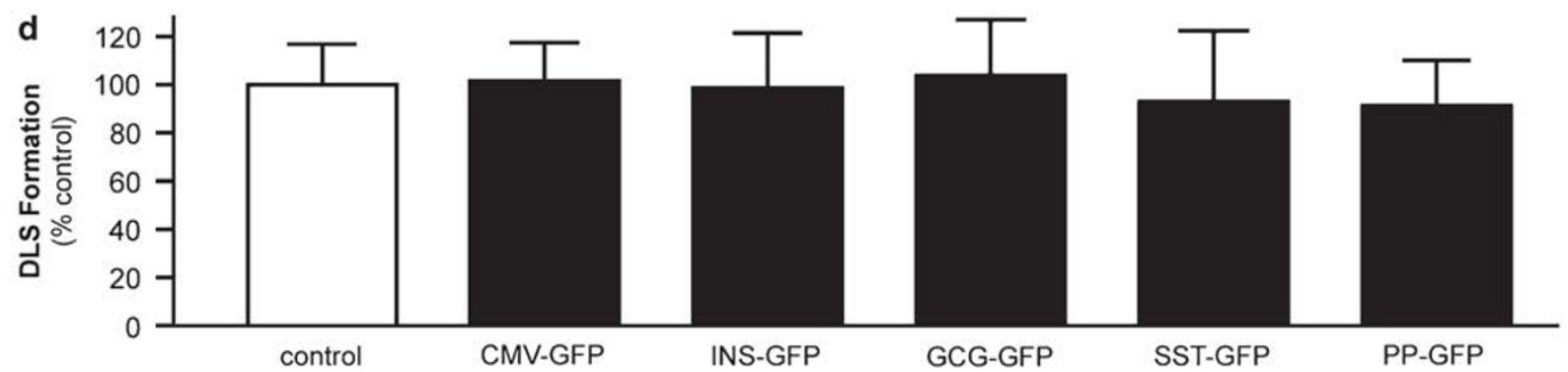

Figure 1 Embedded islets form DLS. (a) Fluorescence microscopy of islet cells, post-infection but pre-embedding, confirms the specificity and efficiency of the GFP-expressing adenoviral vectors. (b) Isolated human islets are solid spherical structures comprised of hormone ${ }^{+}$cells. After collagen embedding and culture, islets form DLS, cystic structures comprised of $\mathrm{CK}^{+}$and nestin ${ }^{+}$cells, as determined by inverted and immunofluorescence microscopy. (c) Quantification of apoptotic cell death before embedding and during the course of DLS formation indicates that $\beta$-cells preferentially undergo apoptosis during DLS formation. (d) Visual assessment of DLS formation after 8 days in culture confirms that adenoviral infection does not affect the ability of islets to form DLS $\left(n=3 ;{ }^{*} P<0.05,{ }^{\uparrow} P<0.01,{ }^{\S} P<0.001\right.$ vs day 0, bar $\left.=100 \mu \mathrm{m}\right)$.

appear to be highly specific, as few promoter-driven $\mathrm{GFP}^{+}$ cells were observed that did not also express the hormone of interest (Table 5).

\section{Duct-Like Structure Formation}

Following collagen embedding and over 8 days of culture, islets became cystic DLS, composed of one to several layers of low cuboidal-type cells in thickness (Figure 1b). Previously, we reported that DLS appeared to form through a combination of $\beta$-cell apoptosis and $\alpha$-, $\delta$ - and PP-cell trans- differentiation. Furthermore, DLS express high levels of epithelial and progenitor markers and low levels of endocrine markers, and have the ability to redifferentiate into islet-like structures given the appropriate stimulus. ${ }^{26}$ It is noteworthy that cells that comprise the DLS appear to be similar to those found in islet monolayers, ${ }^{21-25}$ both with respect to the required culture conditions and the presence of nestin $^{+} /$vimentin $^{+}$and $\mathrm{CK}^{+} / \mathrm{E}$-cadherin ${ }^{+}$cells. $^{26}$

To confirm that selective $\beta$-cell apoptosis was in fact occurring during the process of DLS formation, we assessed 
apoptosis before embedding and at day 2 of culture (Figure 1c), the point of maximal DLS formation. ${ }^{52}$ While little apoptosis was observed in endocrine cells before embedding, DLS formation was associated with a significant increase in apoptosis in all endocrine cells. However, $\beta$-cell apoptosis was the most prevalent, affecting nearly half of $\beta$-cells. Of note, non-endocrine cells also appeared to be affected by ongoing apoptosis.

We have previously reported that the process of DLS formation is complete by 8 days of culture. ${ }^{52}$ Given the apparent unidirectional differentiation occurring in this model, as well as the objective of determining cellular origins, we chose to analyze DLS cultures at this single time point (Figure 2a). By immunofluorescence microscopy, we determined that $40.3 \pm 3.7 \%$ of cells in DLS cultures were $\mathrm{CK}^{+}$ and $17.6 \pm 2.4 \%$ were nestin ${ }^{+}$. Only $11.3 \pm 2.0 \%$ of cells retained hormone expression (Table 4), indicating that the majority of cells either died or became $\mathrm{CK}^{+}$or nestin ${ }^{+}$.

\section{Islet Cell Fate}

To evaluate the fate of specific islet cell types, DLS cultures were assessed by immunofluorescence microscopy to determine the relative frequencies of $\mathrm{GFP}^{+}$cells (Figure $2 \mathrm{~b}$ and c). Only a minority of $\mathrm{GFP}^{+}$cells were also hormone ${ }^{+}$, indicating that most GFP-labeled cells had ceased to express hormone. GFP-labeled $\beta$-cells, however, were more likely than other endocrine cells to retain hormone expression. Moreover, in all samples assessed, no cells were found that coexpressed promoter-driven GFP and any other islet hormone. This suggests that no transdifferentiation from one endocrine cell type to another was occurring in our model. Adenoviral infection did not affect the transformation of islets into DLS (Figure 1d).

With respect to $\mathrm{CK}^{+}$cell formation, a dichotomy was apparent between $\beta$-cells and $\alpha$-, $\delta$ - and PP-cells: $5.0 \pm 5.0 \%$ of $\mathrm{GFP}^{+} \beta$-cells acquired CK expression during DLS formation, as compared to $\sim 75 \%$ of labeled $\alpha$-, $\delta$ - or PP-cells. These results support our previous observations of $\mathrm{CK}^{+} /$ glucagon ${ }^{+}$and $\mathrm{CK}^{+} /$somatostatin $^{+}$double immunofluorescence, without any indication of a $\mathrm{CK}^{+} /$insulin $^{+}$cell population. ${ }^{26}$ The opposite was true with respect to nestin expression: $84.2 \pm 5.1 \%$ of $\mathrm{GFP}^{+} \beta$-cells became nestin ${ }^{+}$, as compared to only $\sim 4 \%$ of labeled $\alpha$-, $\delta$ - or PP-cells.

Few insulin ${ }^{+} /$nestin $^{+}$cells are observed in freshly isolated human islets, ${ }^{54}$ whereas we noted that islets cultured in suspension for 1 week contained $5.2 \pm 1.1 \%$ nestin $^{+}$cells (Table 4 ), most of which were also insulin ${ }^{+}$. One explanation is that $\beta$-cell dedifferentiation is initiated in islets even before embedding. ${ }^{55}$

\section{DLS Cell Origins}

To establish the contributions of individual endocrine cell types to the subpopulations of the DLS, the frequencies of $\mathrm{GFP}^{+} / \mathrm{CK}^{+}$and $\mathrm{GFP}^{+} /$nestin $^{+}$cells were calculated relative to the frequencies of $\mathrm{CK}^{+}$and nestin ${ }^{+}$cells (Table 6).

Accounting for labeling efficiencies, the overall contribution of $\beta$-cells to the $\mathrm{CK}^{+}$cell population was minimal. The contributions of $\alpha$-, $\delta$ - and PP-cells were nearly equal, with each cell type providing approximately one-third of the final $\mathrm{CK}^{+}$cell population. Moreover, based on labeling efficiencies, $\alpha$-, $\delta$ - and PP-cells appeared to be the main contributors to the population of $\mathrm{CK}^{+}$cells.

Conversely, an adjusted $74.4 \pm 0.5 \%$ of nestin ${ }^{+}$cells were of $\beta$-cell origin, with a minimal contribution from $\alpha$-, $\delta$ - and PP-cells. It should be noted, however, that at $6.1 \pm 1.1 \%$, the PP-cell contribution, although minor compared to that of $\beta$-cells, was nevertheless more than that of either $\alpha$ - or $\delta$-cells. Additionally, a significant proportion of nestin ${ }^{+}$cells could not be accounted for by the dedifferentiating $\beta$-cell population, suggesting a possible non-endocrine origin for some of these cells.

\section{Bax Targeting}

To confirm the contribution of specific endocrine cell types to DLS formation, islet cell types were targeted for apoptosis by promoter-mediated Bax expression. Post-infection, samples were assessed for specificity of cell death induction (Figure 3). Cell type-specific Bax expression induced an $\sim 75 \%$ reduction in targeted cell types, without adversely affecting the frequency of other cell types, although overall cell numbers and frequencies were affected accordingly.

Bax-infected cultures were evaluated for DLS formation (Figure 4a) and for the frequencies of the constituent DLS cell subtypes (Figure $4 \mathrm{~b}$ ). Selective $\beta$-cell removal resulted in decreased cystic structure formation, suggesting an important role for $\beta$-cells in this process. Likewise, $\beta$-celldepleted cultures also exhibited a relative decrease in the frequency of nestin ${ }^{+}$DLS cells whereas the frequency of $\mathrm{CK}^{+}$cells increased proportionally.

Targeted depletion of $\alpha$-, $\delta$ - or PP-cells was also associated with decreased cystic structure formation, although $\mathrm{CK}^{+}$ and nestin ${ }^{+}$cell frequencies were unaffected, suggesting a redundancy in the roles of these non- $\beta$-cells in $\mathrm{CK}^{+}$DLS cell formation in that the remaining cell types are able to compensate for the absence of a single specific cell type.

To further clarify the role of individual cell types in DLS formation, additional experiments were carried out in which islets were infected with multiple adenoviral vectors to remove three endocrine cell types, theoretically leaving only one cell type within the islet (Figure 4a). Under these conditions, islets containing primarily $\alpha-, \beta-, \delta$ - or PP-cells displayed reduced rates of DLS formation, coincident with the notion that there is no one cell type that is entirely responsible for DLS cell formation, but rather an interdependence between cell types. Accordingly, removal of one cell type affected the ability of the islet as a whole to form a DLS.

\section{Streptozotocin Treatment}

As an alternative approach to targeted $\beta$-cell death, islets were treated with STZ before embedding. Pre-embedding samples were analyzed to confirm the specificity of cell death induc- 
a
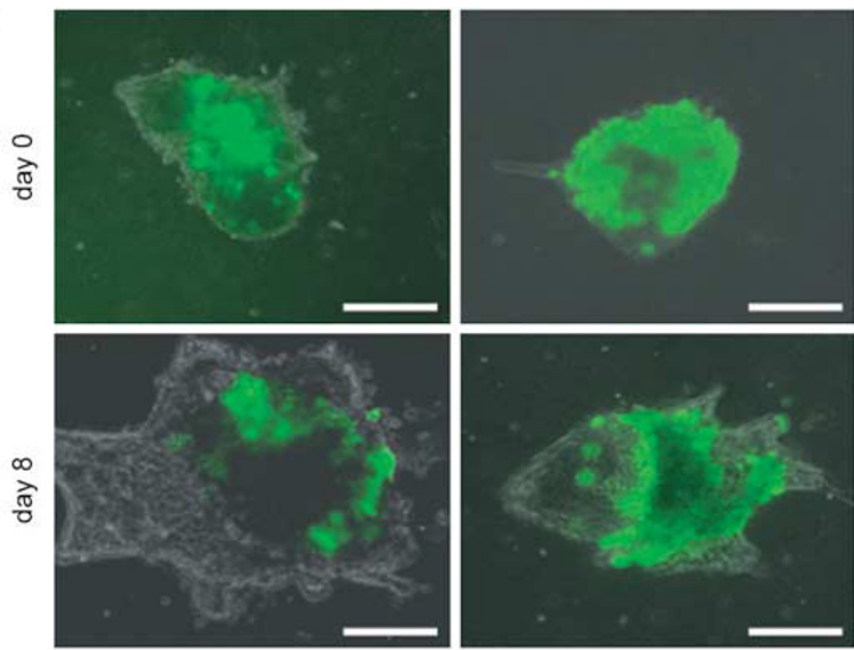

INS-GFP
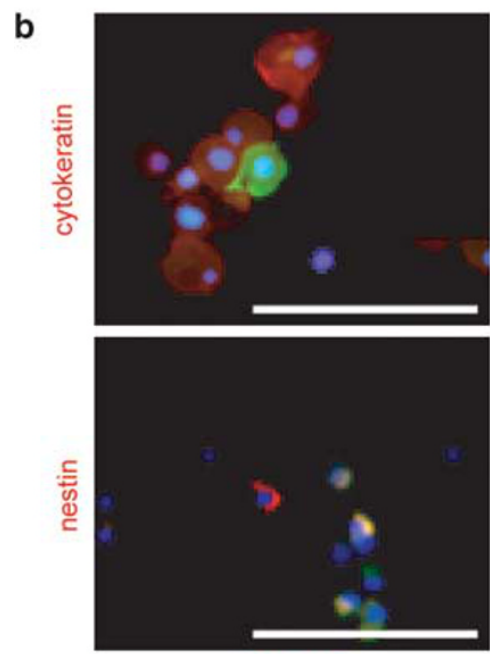

INS-GFP
GCG-GFP
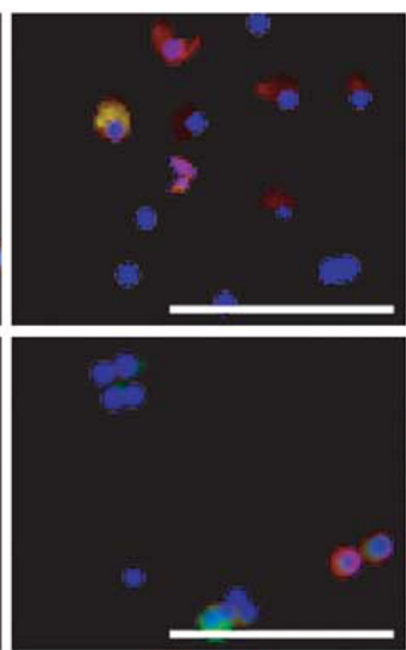

GCG-GFP
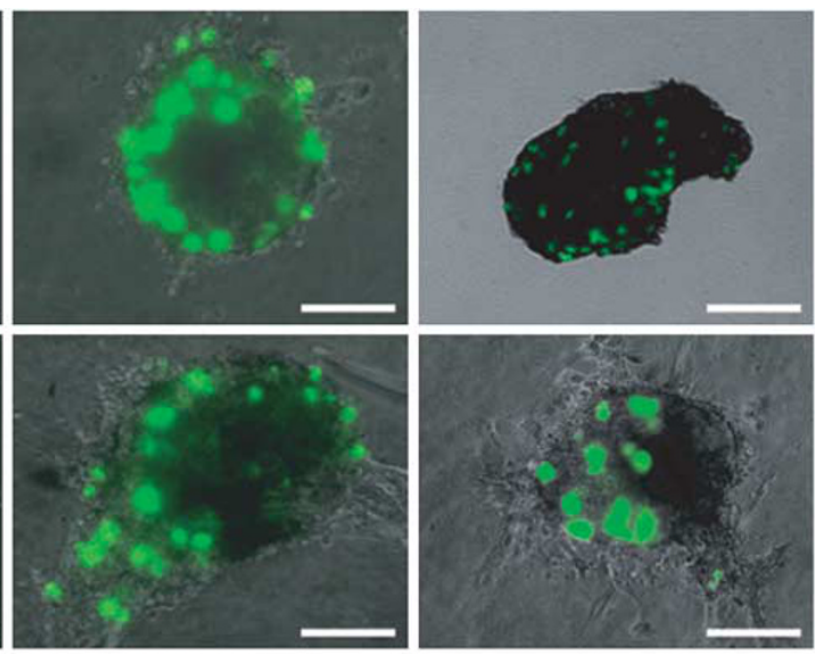

SST-GFP
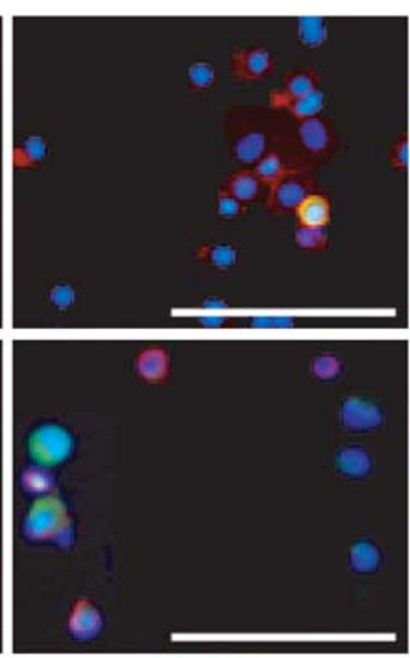

SST-GFP

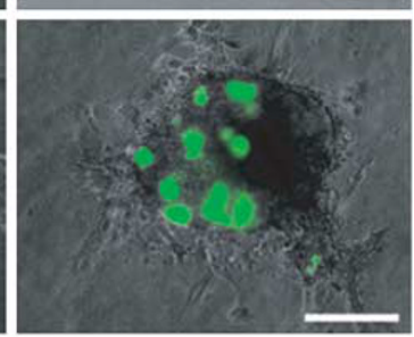

PP-GFP
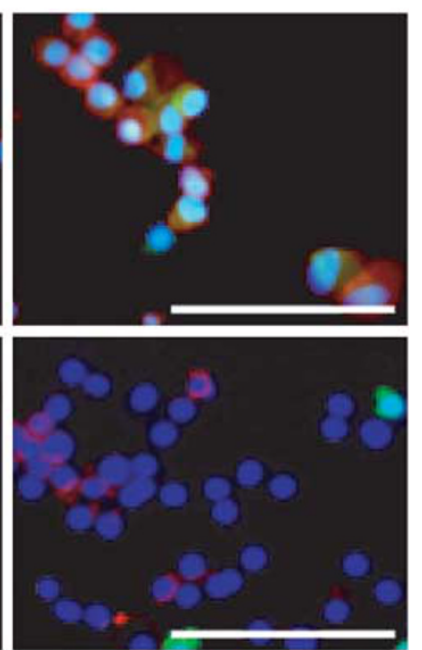

PP-GFP

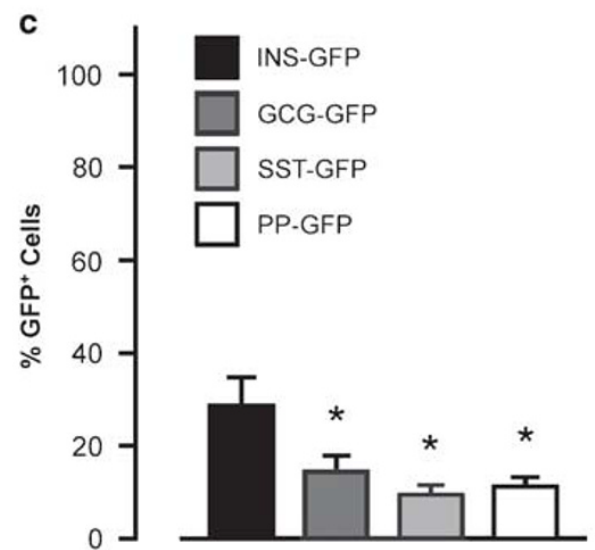

hormone*/GFP*

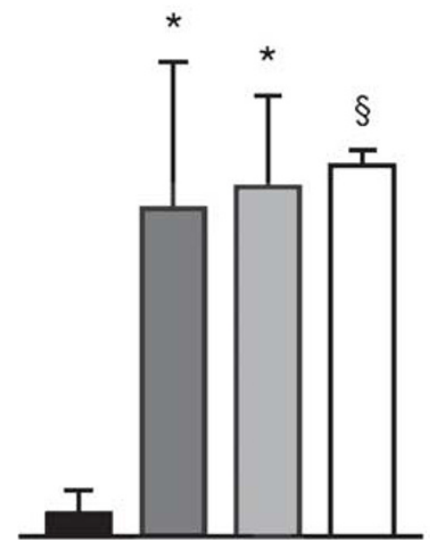

cytokeratin*/GFP*

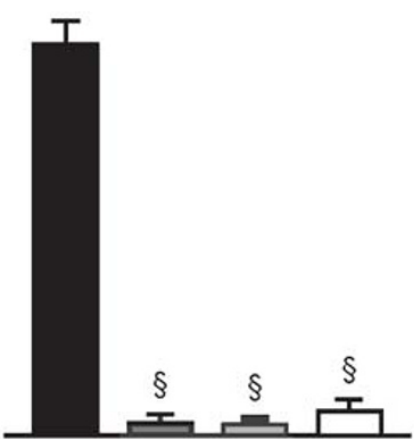

nestin ${ }^{+} /$GFP $^{+}$

Figure 2 GFP labeling allows in vitro cell tracking. (a) Live fluorescence microscopy of embedded islets, both initially and after 8 days in culture, confirms that the GFP label is retained in cells and structures. (b) Fluorescence microscopy of islet-derived cells can be used to determine the fate of labeled cell types. (c) Quantification of GFP ${ }^{+}$cell types indicates that few cells continue to be hormone ${ }^{+}$, whereas many begin to express either CK or nestin $\left(n=3-4 ;{ }^{*} P<0.05,{ }^{\$} P<0.001\right.$ vs INS-GFP; bar $\left.=100 \mu \mathrm{m}\right)$. 
tion (Figure 5a). STZ treatment led to an $\sim 50 \%$ reduction in the frequencies of $\beta$ - and PP-cells, without affecting the frequencies of $\alpha$ - and $\delta$-cells. Assessment of apoptotic indices

Table 6 DLS cell origins

\begin{tabular}{lccrc}
\hline Vector & $\mathrm{GFP}^{+} / \mathrm{CK}^{+}\left(\% \mathrm{CK}^{+}\right)$ & $\times$Efficiency $^{-1}(\%)=$ Origin (\%) & $n$ \\
\hline INS-GFP & $0.5 \pm 0.6$ & $35.0 \pm 3.4$ & $1.4 \pm 4.2$ & 4 \\
GCG-GFP & $19.1 \pm 4.1$ & $49.8 \pm 0.8$ & $38.4 \pm 4.1$ & 3 \\
SST-GFP & $15.4 \pm 3.4$ & $46.3 \pm 3.2$ & $33.3 \pm 5.2$ & 4 \\
PP-GFP & $15.9 \pm 2.1$ & $43.9 \pm 1.9$ & $36.2 \pm 2.8$ & 3
\end{tabular}

Vector $\mathrm{GFP}^{+} /$nestin $^{+}\left(\%\right.$ nestin $\left.{ }^{+}\right) \times$Efficiency $^{-1}(\%)=$ Origin (\%) $n$

\begin{tabular}{|c|c|c|c|}
\hline INS-GFP & $26.0 \pm 0.7$ & $35.0 \pm 3.4$ & $74.4 \pm 0.5 \quad 4$ \\
\hline GCG-GFP & $1.6 \pm 1.1$ & $49.8 \pm 0.8$ & $3.3 \pm 1.1 \quad 3$ \\
\hline SST-GFP & $1.0 \pm 0.7$ & $46.3 \pm 3.2$ & $2.3 \pm 0.6 \quad 4$ \\
\hline PP-GFP & $2.7 \pm 1.1$ & $43.9 \pm 1.9$ & $6.1 \pm 1.1 \quad 3$ \\
\hline
\end{tabular}

DLS, duct-like structures. further confirmed the specificity of $\beta$ - and PP-cell death (Figure $5 b$ ).

STZ-treated islets were evaluated for DLS formation (Figure 5c) and the frequencies of DLS cell types (Figure 5d). Surprisingly, STZ treatment had no effect on cystic structure formation. This result appears at odds with the results of the Bax expression experiments (Figure 4a) that suggested that the removal of any single endocrine cell type impairs DLS formation. As Bax expression reduced target cell type frequencies by $\sim 75 \%$, whereas STZ treatment reduced $\beta$ - and PP-cell numbers by only $\sim 50 \%$, it is possible that a threshold exists whereby islets can withstand limited cellular depletion without differentiation being affected.

As for DLS cell types, the removal of $\sim 50 \%$ of PP-cells did not adversely affect the $\mathrm{CK}^{+}$cell frequency, which was to be expected given the apparent redundancy of $\alpha$-, $\delta$ - and PPcells with respect to their contribution to dedifferentiation. STZ-mediated removal of $\sim 50 \%$ of $\beta$-cells in islets translated to a significant reduction in the frequency of nestin ${ }^{+}$cells within the DLS, confirming earlier observations of DLS cell origin.
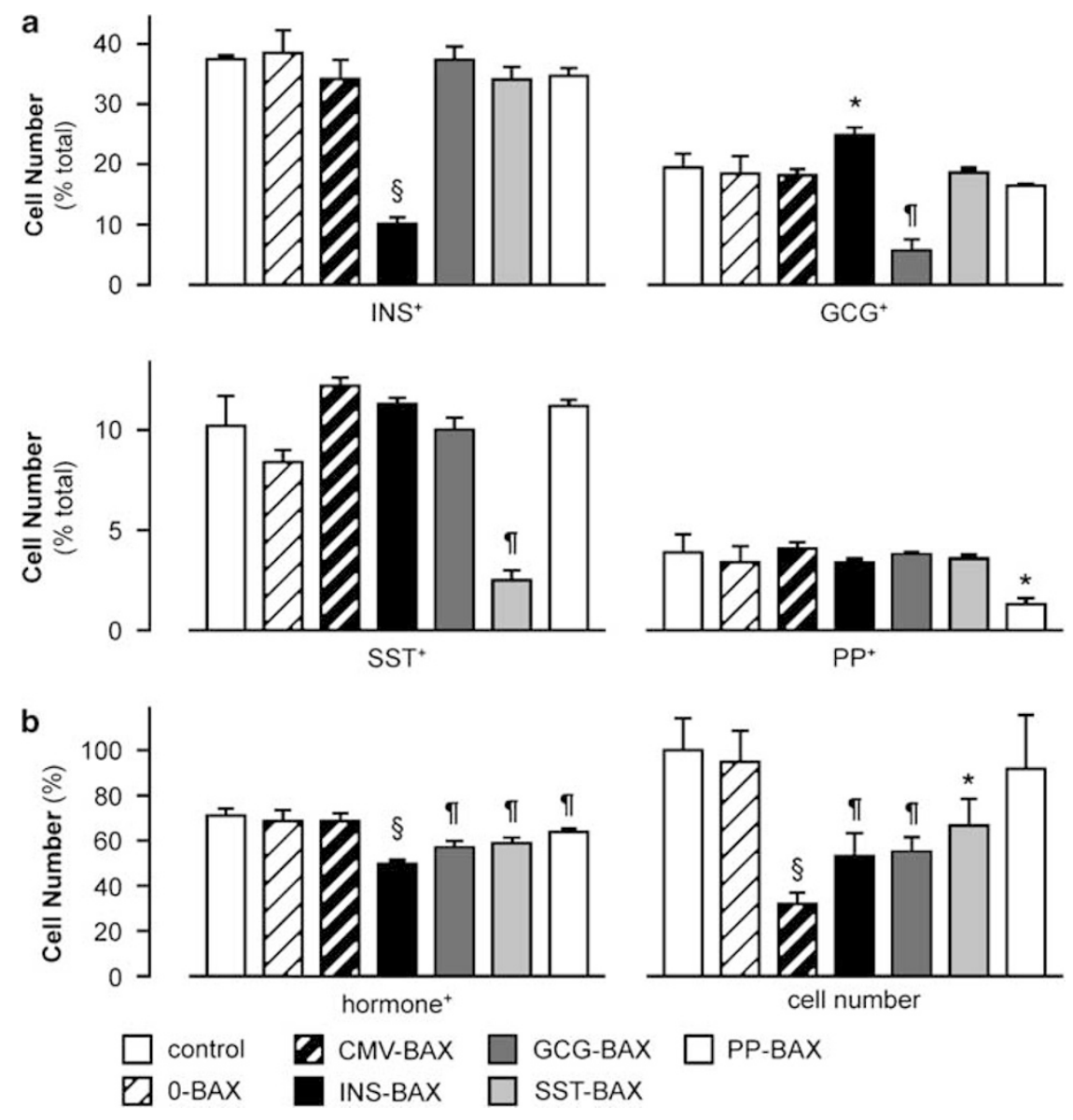

$$
\text { hormone }^{+}
$$

cell number

Figure 3 Bax expression allows inverse cell tracking. (a) Quantification of islet cell frequencies, post-infection but before embedding, confirms the specificity and efficiency of the Bax-expressing adenoviral vectors. (b) Quantification of the frequency of hormone ${ }^{+}$islet cells, as well as overall cell numbers, post-infection but before embedding, confirms the specificity and efficiency of the Bax-expressing adenoviral vectors employed $(n=3$; ${ }^{\star} P<0.05,{ }^{P} P<0.01,{ }^{\S} P<0.001$ vs control, all others NS). 


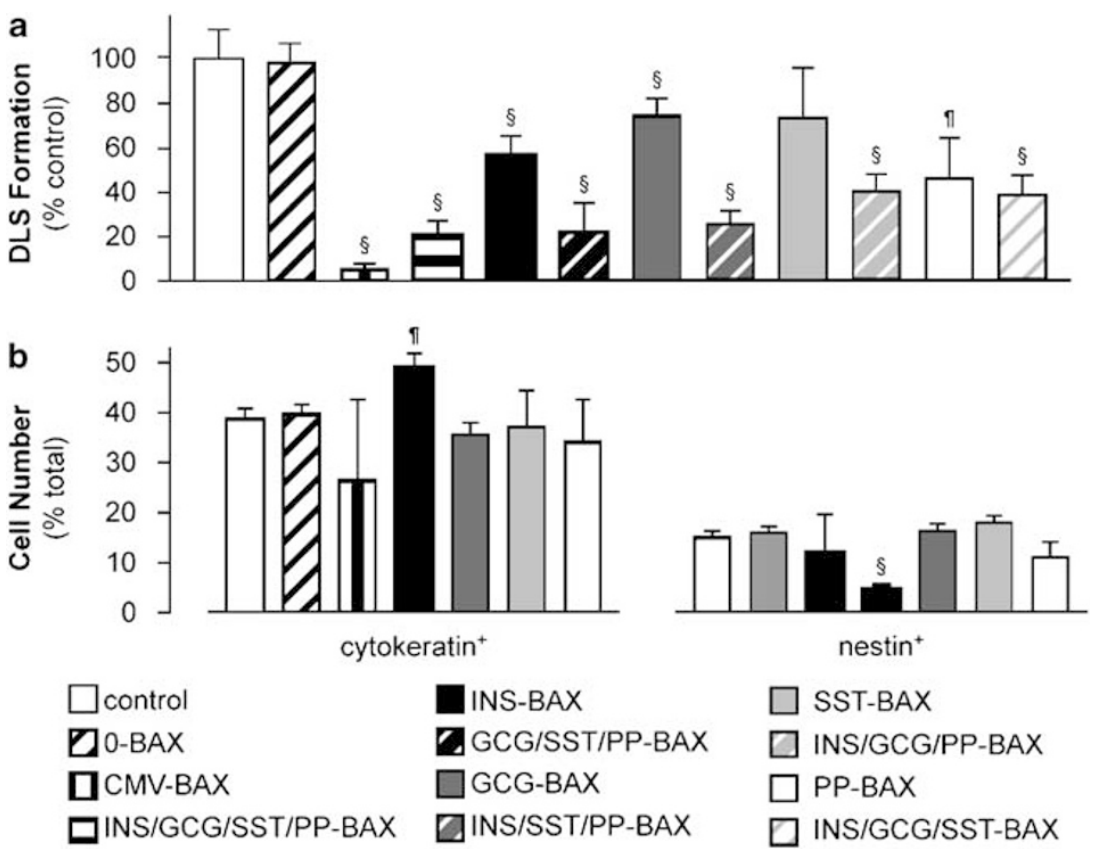

Figure 4 Islet cell interdependence and redundancy. (a) Visual assessment of DLS formation after 8 days in culture confirms the interdependence of islet cell types in that selective depletion of any individual cell type adversely affects DLS formation. (b) Quantification of $\mathrm{CK}^{+}$and nestin ${ }^{+}$islet-derived cell frequencies indicates that $\alpha$-, $\delta$ - and PP-cell-derived $\mathrm{CK}^{+}$cells increase in number to compensate for the reduced frequency of $\beta$-cell-derived nestin $^{+}$cells in DLS derived from $\beta$-cell-depleted islets. Moreover, redundancy exists in that $\alpha$-, $\delta$ - and PP-cells appear to compensate for a lack of any of these cell types so as to maintain the frequency of $\mathrm{CK}^{+}$cells in DLS derived from $\alpha$-, $\delta$ - or PP-cell-depleted islets $\left(n=3 ;{ }^{*} P<0.05,{ }^{\circledR} P<0.01\right.$, $\S_{P}<0.001$ vs control).

\section{Islet Redifferentiation}

We have previously established that DLS can be induced to redifferentiate into islet-like structures given the appropriate stimulus. ${ }^{26}$ To identify the precursor-type cell(s) responsible for islet redifferentiation in this model, we fed cultures of DLS from STZ-treated islets with a redifferentiation medium, with or without INGAP peptide, for 4 days (Figure 5e). Control cultures responded to the redifferentiation medium with a $14.2 \pm 5.3 \%$ increase in the frequency of dithizone ${ }^{+}$ structures, whereas INGAP peptide administration increased this effect to $26.2 \pm 4.4 \%$. Conversely, STZ-treated cultures did not respond to either the redifferentiation medium alone or in combination with INGAP peptide, indicating a deficiency in redifferentiation in DLS formed from STZ-treated cultures.

\section{DISCUSSION}

Under specific culture conditions, cultured human islets appear to lose their endocrine phenotype and are replaced by a heterogeneous population of seemingly primitive, highly proliferative cells. ${ }^{21-26,51,55,56}$ Recently, investigators have identified culture conditions under which these cells can be induced to redifferentiate into islet-like structures, albeit with varying degrees of endocrine phenotype and function, ${ }^{22-26}$ thereby lending support to the hypothesis that islet-derived cells can act as precursors. Although encouraging, these reports have been met with controversy.
Previous reports have presented evidence, including electron microscopy of individual cells with both endocrine (endosecretory granules) and ductal (microvilli) characteristics, and double immunofluorescence microscopy of cells coexpressing endocrine hormones and duct cell markers, suggesting that these precursor-type cells derive from adult endocrine cell types. ${ }^{23,26,55}$ However, lineage tracing and pulse-chase studies in mice have suggested that the primary mechanism of both $\beta$-cell renewal and regeneration in the endogenous pancreas is $\beta$-cell replication. ${ }^{19,20}$ More recently, yet another lineage tracing study concluded that the fibroblast-like cells observed in mouse islet cultures do not derive from cells of any pancreatic lineage. ${ }^{28}$ These discrepancies between human and rodent studies led us to employ other methods to confirm our previous double immunofluorescence-based observations of an $\alpha$ - and $\delta$-cell origin for the $\mathrm{CK}^{+}$population that is observed to arise. ${ }^{26}$

In the present study, we employed a newly validated adenoviral coinfection technique to serve as a signal amplifier. ${ }^{35}$ In this way, we transiently labeled individual endocrine cell types with reproducible efficiency and high specificity. Given the strength and cumulative half-lives of the transactivator and GFP, we were able to follow specific endocrine cell types, even after the promoters of interest were no longer active in the dedifferentiated cells. Thus, we observed that in our culture system, both $\mathrm{CK}^{+}$epithelial cells and nestin ${ }^{+}$fi- $^{-}$ broblast-like cells derive from hormone-expressing endocrine cells, albeit from different endocrine cell types. 
a

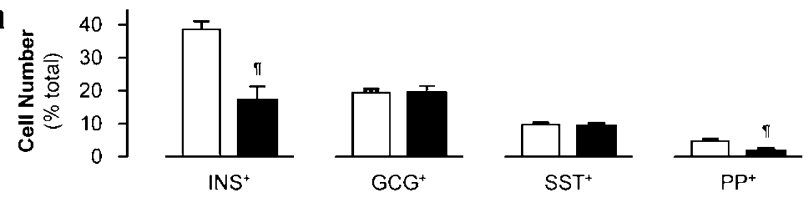

b

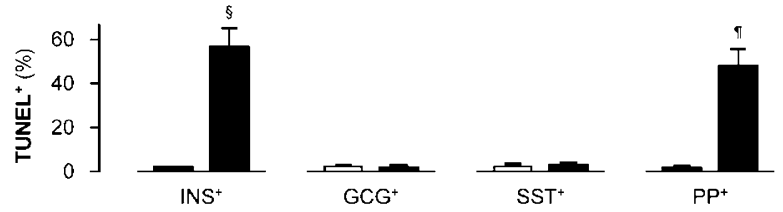

C
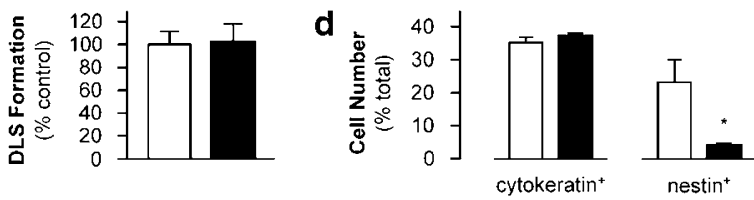

e

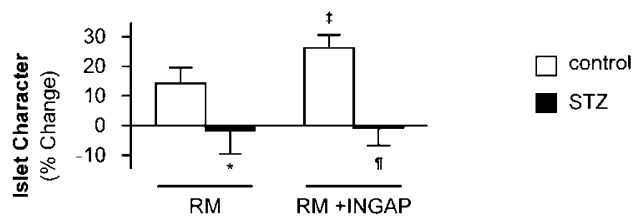

Figure 5 Streptozotocin treatment confirms inverse cell tracking. (a) Quantification of islet cell frequencies and (b) apoptotic cell death after STZ treatment but before embedding indicates that STZ selectively targets $\beta$ - and PP-cells. (c) STZ treatment does not affect DLS formation, as evaluated visually after 8 days in culture. (d) The frequency of $\mathrm{CK}^{+}$DLS cells is unaffected by islet STZ treatment before embedding, but the frequency of nestin ${ }^{+}$DLS cells is reduced. (e) After culture to form DLS, switching to redifferentiation medium (RM) allows a spontaneous reversion of DLS into dithizone $^{+}$islet-like structures, which is potentiated by INGAP peptide. STZ treatment of islets before culture abrogates the redifferentiation response of DLS, both with and without INGAP peptide $\left(n=4 ;{ }^{*} P<0.05,{ }^{\circ} P<0.01\right.$ vs same conditions for control, ${ }^{\ddagger} P<0.05$ vs RM for control).

Our results suggest that the $\mathrm{CK}^{+}$epithelial cells of DLS derive primarily from glucagon ${ }^{+}$, somatostatin ${ }^{+}$and pancreatic polypeptide $^{+}$cells, with approximately equal contributions from each, while very few $\mathrm{CK}^{+}$cells derive from insulin ${ }^{+}$cells. Conversely, nestin ${ }^{+}$cells derive mainly from insulin ${ }^{+}$cells, while mantle cells contribute little. The possibility exists, however, that nestin ${ }^{+}$cells also derive from non-endocrine cell origins, as a significant number of nestin ${ }^{+}$cells were not accounted for by labeled endocrine cells.

As with any promoter-based expression system, it is important to note that cell types were defined based only on the activity of a single promoter sequence. ${ }^{19}$ Thus, a $\beta$-cell was defined based on the presence of an active insulin promoter at the time of culture. Accordingly, data from such studies must be interpreted with this in mind, because sub-populations of islet cells that are insulin ${ }^{+}$, but would not be considered adult $\beta$-cells, have been reported previously. ${ }^{57} \mathrm{To}$ our knowledge, this is the first report of human promoter sequences being used to label human islets.

With respect to lineage tracing studies, Dor et al ${ }^{19}$ acknowledged the possibility of an insulin ${ }^{+}$precursor cell that would be labeled as a $\beta$-cell in lineage tracing studies.
This notion is especially appealing in our in vitro islet culture system, because we followed not only insulin ${ }^{+}$cells, but also the four principal endocrine cells of the islet. Our studies led to the novel observation that there was a dichotomy with respect to the cellular origins of the two primary cell types of the DLS: $\mathrm{CK}^{+}$cells derive primarily from $\alpha-, \delta$ - and PP-cells, and nestin ${ }^{+}$cells derive mainly from $\beta$-cells.

Targeted depletion of specific cell types by adenoviral expression of Bax or STZ treatment was originally performed with the intention of identifying the cell(s) responsible for the redifferentiation potential of DLS. As such, the lack of redifferentiation from DLS derived from STZ-treated islets suggests an important role for $\beta$ - and PP-cell-derived cells. However, these results also serve to highlight the interdependence of endocrine cell types with respect to DLS formation and, presumably, islet regeneration. Thus, no cell type can yet be proposed as an in vitro islet precursor without true lineage tracing of the islet regeneration process. In fact, it may well be that cells exist as facultative precursors only within the niche defined by DLS or monolayer cultures. ${ }^{58}$ It is for this reason that studies of redifferentiation of Bax-treated cultures could not be carried out, for in an attempt to remove an individual cell type from the niche, the niche itself was disrupted.

Characterization of the starting tissue in these experiments indicates a weak presence of $\mathrm{CK}^{+}$and nestin ${ }^{+}$cells from the beginning, and thus the proliferation of these cells could have possibly contributed to the resultant cell populations. However, correcting for labeling efficiencies suggests that virtually all $\mathrm{CK}^{+}$cells were in fact derived from endocrine cells over the course of culture. Likewise, BrdU labeling studies carried out previously indicated that the proliferation of $\mathrm{CK}^{+}$cells does not begin immediately, but only after several days in culture, following the main wave of dedifferentiation. ${ }^{52,59}$ Finally, we do not presume to exclude a contribution of some inherent ductal or fibroblastic cells in our preliminary cultures, but rather we are reporting on the origins of cells that seem to account for a majority of the $\mathrm{CK}^{+}$and nestin ${ }^{+}$cells present at the end of the culture period. In fact, to pinpoint the exact source of in vitro islet neogenesis, long-term lineage tracing studies using indelible cell markers would be required. These experiments are beyond the scope of these studies, however, as we sought only to identify the endocrine cell origins of cells within the DLS.

Other groups have reported on monolayers formed from cultured islets, ${ }^{22-25,33}$ whereas our model involves threedimensional organotypic culture. ${ }^{26}$ Nonetheless, it seems that the precursor-type cells we observe are very similar to those reported in monolayer culture, especially when the culture conditions and expression profile of both cell populations are considered. As in the monolayer, we observe two predominant cell types: the majority of cells are $\mathrm{CK}^{+}$and epithelial in nature, whereas a less frequent nestin ${ }^{+}$fibroblastlike cells also exist within the DLS. Additionally, there is heterogeneity of both $\mathrm{Pdx} 1$ and vimentin expression, as in the monolayer. ${ }^{26}$ 
At first glance, our results may appear to contradict those reported by others who have conducted lineage tracing studies in mice. ${ }^{28}$ However, evidence is accumulating to suggest that the non-human pancreas is not always an appropriate model to study phenomena occurring in the human organ. ${ }^{60}$ For example, recent reports aimed at elucidating the islet regenerative response in humans and mice indicated that humans increase $\beta$-cell mass primarily through neogenesis, ${ }^{2}$ whereas the mouse regenerative response involves $\beta$-cell replication. ${ }^{32}$ Likewise, cultured human islets have been reported to form precursor cell cultures that can be induced to redifferentiate into islet-like structures. ${ }^{22-26}$ When similar culture conditions were applied to mouse islets, little if any redifferentiation was observed. ${ }^{27,28,30,61}$ Taken together, these data suggest a difference with respect to the mechanisms of regeneration that predominate in human and non-human tissue. Consequently, although certainly informative, the results of lineage tracing studies in mice may not necessarily be informative of what transpires in man. In fact, a recent study using a similar lineage tracing technique confirmed that human, but not murine, $\beta$-cells were capable of significant in vitro dedifferentiation and proliferation. ${ }^{33}$

Finally, a debate persists over the cellular source of in vitro islet redifferentiation. Given the presence of $\beta$-cells, non- $\beta$-endocrine cells and non-endocrine cells in islet cultures, the mechanisms involved may represent $\beta$-cell neogenesis, proliferation or both. For example, if islet-like structures were observed to form from the $\mathrm{CK}^{+}$epithelial cell source, which is almost exclusively of non- $\beta$-cell origin, this could be termed islet neogenesis. Immunofluorescence and BrdU pulse-chase studies have provided support for this pathway. ${ }^{21,26}$ Conversely, if $\beta$-cell-derived nestin ${ }^{+}$cells are observed to give rise to islet-like structures, then this could be defined as $\beta$-cell replication, albeit indirect, given the presence of an intermediate cell type. ${ }^{17}$ Immunofluorescence studies provide tentative support for this mechanism as well. ${ }^{22}$ Thus, our findings do not rule out either pathway of $\beta$-cell formation. Additional longer-term lineage tracing studies would undoubtedly prove useful in elucidating a predominant mechanism.

\section{ACKNOWLEDGEMENTS}

We thank Béatrice Assouline, Emily Austin, Mauro Castellarin, Jieping Ding, Deborah Driver, Xinfang Li, Mark Lipsett, Julia Makhlin, Mandana Moosavi and Ryan Scott for technical assistance, as well as Québec-Transplant for coordination of organ availability. This work was supported in part by the Canadian Institutes of Health Research (CIHR) and the Stem Cell Network of Canada. SC Hanley is supported by fellowships from the Canadian Diabetes Association/CIHR and Fonds de Recherche en Santé du Québec (FRSQ). L Rosenberg has been supported as a chercheur national (national scientist) of the FRSQ. Grant support was provided by Canadian Institutes of Health Research, Stem Cell Network of Canada.

1. Scaglia L, Smith FE, Bonner-Weir S. Apoptosis contributes to the involution of beta cell mass in the post partum rat pancreas. Endocrinology 1995;136:5461-5468.
2. Butler $A E$, Janson J, Bonner-Weir $\mathrm{S}$, et al. Beta-cell deficit and increased beta-cell apoptosis in humans with type 2 diabetes. Diabetes 2003;52:102-110.

3. Lipsett MA, Austin EB, Castellarin ML, et al. Evidence for the homeostatic regulation of induced beta cell mass expansion. Diabetologia 2006;49:2910-2919.

4. Finegood DT, Scaglia L, Bonner-Weir S. Dynamics of beta-cell mass in the growing rat pancreas. Estimation with a simple mathematical model. Diabetes 1995:44:249-256.

5. Rosenberg L, Brown RA, Duguid WP. A new approach to the induction of duct epithelial hyperplasia and nesidioblastosis by cellophane wrapping of the hamster pancreas. J Surg Res 1983;35: 63-72.

6. Bonner-Weir S, Baxter LA, Schuppin GT, et al. A second pathway for regeneration of adult exocrine and endocrine pancreas. A possible recapitulation of embryonic development. Diabetes 1993;42: 1715-1720.

7. Pictet RL, Rutter WJ. Development of the embryonic endocrine pancreas. In: Steiner D, Freinkel N (eds). Handbook of Physiology. Williams and Wilkins: Baltimore, MD, 1972, pp 25-66.

8. Lipsett $M$, Finegood DT. Beta-cell neogenesis during prolonged hyperglycemia in rats. Diabetes 2002;51:1834-1841.

9. Rooman I, Lardon J, Bouwens L. Gastrin stimulates beta-cell neogenesis and increases islet mass from transdifferentiated but not from normal exocrine pancreas tissue. Diabetes 2002;51:686-690.

10. Fernandes A, King LC, Guz Y, et al. Differentiation of new insulinproducing cells is induced by injury in adult pancreatic islets. Endocrinology 1997;138:1750-1762.

11. Guz Y, Nasir I, Teitelman G. Regeneration of pancreatic beta cells from intra-islet precursor cells in an experimental model of diabetes. Endocrinology 2001;142:4956-4968.

12. Zulewski H, Abraham EJ, Gerlach MJ, et al. Multipotential nestinpositive stem cells isolated from adult pancreatic islets differentiate ex vivo into pancreatic endocrine, exocrine, and hepatic phenotypes. Diabetes 2001;50:521-533.

13. Li L, Seno $M$, Yamada $H$, et al. Betacellulin improves glucose metabolism by promoting conversion of intraislet precursor cells to beta-cells in streptozotocin-treated mice. Am J Physiol Endocrinol Metab 2003;285:E577-E583.

14. Bonner-Weir S, Taneja M, Weir GC, et al. In vitro cultivation of human islets from expanded ductal tissue. Proc Natl Acad Sci USA 2000;97:7999-8004.

15. Hao $E$, Tyrberg $B$, Itkin-Ansari $P$, et al. Beta-cell differentiation from nonendocrine epithelial cells of the adult human pancreas. Nat Med 2006;12:310-316.

16. Lipsett MA, Castellarin ML, Rosenberg L. Acinar plasticity: development of a novel in vitro model to study human acinar-to-duct-to-islet differentiation. Pancreas 2007;34:452-457.

17. Dor Y. Beta-cell proliferation is the major source of new pancreatic beta cells. Nat Clin Pract Endocrinol Metab 2006;2:242-243.

18. Bonner-Weir $S$, Sharma A. Are there pancreatic progenitor cells from which new islets form after birth? Nat Clin Pract Endocrinol Metab 2006;2:240-241.

19. Dor Y, Brown J, Martinez Ol, et al. Adult pancreatic beta-cells are formed by self-duplication rather than stem-cell differentiation. Nature 2004;429:41-46.

20. Teta M, Rankin MM, Long SY, et al. Growth and regeneration of adult beta cells does not involve specialized progenitors. Dev Cell 2007;12:817-826.

21. Gao R, Ustinov J, Pulkkinen MA, et al. Characterization of endocrine progenitor cells and critical factors for their differentiation in human adult pancreatic cell culture. Diabetes 2003;52: 2007-2015.

22. Gershengorn MC, Hardikar AA, Wei C, et al. Epithelial-to-mesenchymal transition generates proliferative human islet precursor cells. Science 2004;306:2261-2264.

23. Gao R, Ustinov J, Korsgren $\mathrm{O}$, et al. In vitro neogenesis of human islets reflects the plasticity of differentiated human pancreatic cells. Diabetologia 2005;48:2296-2304.

24. Lechner A, Nolan AL, Blacken RA, et al. Redifferentiation of insulinsecreting cells after in vitro expansion of adult human pancreatic islet tissue. Biochem Biophys Res Commun 2005;327:581-588. 
25. Ouziel-Yahalom L, Zalzman M, Anker-Kitai L, et al. Expansion and redifferentiation of adult human pancreatic islet cells. Biochem Biophys Res Commun 2006;341:291-298.

26. Jamal AM, Lipsett $M$, Sladek $R$, et al. Morphogenetic plasticity of adult human pancreatic islets of Langerhans. Cell Death Differ 2005;12: 702-712.

27. Atouf $\mathrm{F}$, Park $\mathrm{CH}$, Pechhold $\mathrm{K}$, et al. No evidence for mouse pancreatic beta-cell epithelial-mesenchymal transition in vitro. Diabetes 2007;56:699-702.

28. Chase LG, Ulloa-Montoya F, Kidder BL, et al. Islet-derived fibroblast-like cells are not derived via epithelial-mesenchymal transition from $\mathrm{Pdx}-1$ or insulin-positive cells. Diabetes 2007;56:3-7.

29. Morton RA, Geras-Raaka E, Wilson LM, et al. Endocrine precursor cells from mouse islets are not generated by epithelial-to-mesenchymal transition of mature beta cells. Mol Cell Endocrinol 2007;270:87-93.

30. Weinberg N, Ouziel-Yahalom L, Knoller S, et al. Lineage tracing evidence for in-vitro dedifferentiation, but rare proliferation, of mouse pancreatic beta cells. Diabetes 2007;56:1299-1304.

31. Gannon M, Herrera PL, Wright CV. Mosaic Cre-mediated recombination in pancreas using the pdx-1 enhancer/promoter. Genesis 2000;26: 143-144.

32. Butler $A E$, Janson J, Soeller WC, et al. Increased beta-cell apoptosis prevents adaptive increase in beta-cell mass in mouse model of type 2 diabetes: evidence for role of islet amyloid formation rather than direct action of amyloid. Diabetes 2003;52:2304-2314.

33. Russ HA, Bar $Y$, Ravassard $P$, et al. In vitro proliferation of cells derived from adult human beta-cells revealed by cell-lineage tracing. Diabetes 2008 (in press).

34. Massie B, Couture F, Lamoureux L, et al. Inducible overexpression of toxic protein by an adenovirus vector with a tetracycline-regulatable expression cassette. J Virol 1998;72:2289-2296.

35. Mullick A, Xu Y, Warren R, et al. The cumate gene-switch: a system fo regulated expression in mammalian cells. BMC Biotechnol 2006;6:43.

36. Baulcombe DC, Chapman S, Santa Cruz S. Jellyfish green fluorescent protein as a reporter for virus infections. Plant J 1995;7:1045-1053.

37. Lottmann $\mathrm{H}$, Vanselow J, Hessabi B, et al. The Tet-On system in transgenic mice: inhibition of the mouse pdx-1 gene activity by antisense RNA expression in pancreatic beta-cells. J Mol Med 2001;79:321-328.

38. Milo-Landesman D, Surana M, Berkovich I, et al. Correction of hyperglycemia in diabetic mice transplanted with reversibly immortalized pancreatic beta cells controlled by the tet-on regulatory system. Cell Transplant 2001;10:645-650.

39. Bell Gl, Pictet RL, Rutter WJ, et al. Sequence of the human insulin gene. Nature 1980;284:26-32.

40. Burkhardt BR, Loiler SA, Anderson JA, et al. Glucose-responsive expression of the human insulin promoter in HepG2 human hepatoma cells. Ann NY Acad Sci 2003;1005:237-241.

41. White JW, Saunders GF. Structure of the human glucagon gene Nucleic Acids Res 1986;14:4719-4730.

42. Nian M, Gu J, Irwin DM, et al. Human glucagon gene promoter sequences regulating tissue-specific versus nutrient-regulated gene expression. Am J Physiol Regul Integr Comp Physiol 2002;282: R173-R183.

43. Shen LP, Pictet RL, Rutter WJ. Human somatostatin I: sequence of the cDNA. Proc Natl Acad Sci USA 1982;79:4575-4579.
44. Goudet G, Delhalle S, Biemar F, et al. Functional and cooperative interactions between the homeodomain PDX1, Pbx, and Prep1 factors on the somatostatin promoter. J Biol Chem 1999;274:4067-4073.

45. Leiter $A B$, Montminy MR, Jamieson $E$, et al. Exons of the human pancreatic polypeptide gene define functional domains of the precursor. J Biol Chem 1985;260:13013-13017.

46. Pirocanac EC, Nassirpour R, Yang M, et al. Bax-induction gene therapy of pancreatic cancer. J Surg Res 2002;106:346-351.

47. Elahi SM, Oualikene W, Naghdi L, et al. Adenovirus-based libraries: efficient generation of recombinant adenoviruses by positive selection with the adenovirus protease. Gene Therapy 2002:9:1238-1246.

48. Ogorelkova M, Elahi SM, Gagnon D, et al. DNA delivery to cells in culture: generation of adenoviral libraries for high-throughput functional screening. Methods Mol Biol (Clifton, NJ) 2004;246:15-27.

49. Durocher $Y$, Perret S, Kamen A. High-level and high-throughput recombinant protein production by transient transfection of suspension-growing human 293-EBNA1 cells. Nucleic Acids Res 2002;30:E9.

50. Ricordi C, Lacy PE, Finke EH, et al. Automated method for isolation of human pancreatic islets. Diabetes 1988;37:413-420.

51. Yuan S, Rosenberg L, Paraskevas $S$, et al. Transdifferentiation of human islets to pancreatic ductal cells in collagen matrix culture. Differentiation 1996;61:67-75.

52. Hanley S, Rosenberg L. Transforming growth factor-beta is a critical regulator of adult human islet plasticity. Mol Endocrinol 2007;21: 1467-1477.

53. Brissova M, Fowler MJ, Nicholson WE, et al. Assessment of human pancreatic islet architecture and composition by laser scanning confocal microscopy. J Histochem Cytochem 2005;53: 1087-1097.

54. Street CN, Lakey JR, Seeberger K, et al. Heterogenous expression of nestin in human pancreatic tissue precludes its use as an islet precursor marker. J Endocrinol 2004;180:213-225.

55. Schmied BM, Ulrich A, Matsuzaki $H$, et al. Transdifferentiation of human islet cells in a long-term culture. Pancreas 2001;23:157-171.

56. Lechner A, Leech CA, Abraham EJ, et al. Nestin-positive progenitor cells derived from adult human pancreatic islets of Langerhans contain side population (SP) cells defined by expression of the ABCG2 (BCRP1) ATPbinding cassette transporter. Biochem Biophys Res Commun 2002;293:670-674

57. Petropavlovskaia M, Rosenberg L. Identification and characterization of small cells in the adult pancreas: potential progenitor cells? Cell Tissue Res 2002;310:51-58.

58. Fuchs E, Tumbar T, Guasch G. Socializing with the neighbors: stem cells and their niche. Cell 2004;116:769-778.

59. Jamal AM, Lipsett $M$, Hazrati $A$, et al. Signals for death and differentiation: a two-step mechanism for in vitro transformation of adult islets of Langerhans to duct epithelial structures. Cell Death Differ 2003;10:987-996.

60. Case RM. Is the rat pancreas an appropriate model of the human pancreas? Pancreatology 2006;6:180-190.

61. Morton RA, Geras-Raaka E, Wilson LM, et al. Endocrine precursor cells from mouse islets are not generated by epithelial-tomesenchymal transition of mature beta cells. Mol Cell Endocrinol 2007;270:87-93. 